\title{
Field Measurement of Cotton Seedling Evapotranspiration
}

\author{
R. J. Lascano1 ${ }^{*}$, J. L. Duesterhaus ${ }^{2}$, J. D. Booker ${ }^{3}$, T. S. Goebel1, J. T. Baker ${ }^{4}$ \\ ${ }^{1}$ USDA-ARS", Wind Erosion and Water Conservation Research Unit, Plant Stress and Water Conservation \\ Laboratory, Lubbock, TX, USA \\ ${ }^{2}$ USDA-ARS, Former Postdoctoral Research Associate, Wind Erosion and Water Conservation Research Unit, \\ Plant Stress and Water Conservation Laboratory, Lubbock, TX, USA \\ ${ }^{3}$ Plant and Soil Sciences Department, Texas Tech University, Lubbock, TX, USA \\ ${ }^{4}$ USDA-ARS, Wind Erosion and Water Conservation Research Unit, Plant Stress and Water Conservation \\ Laboratory, Big Spring, TX, USA \\ Email: ${ }^{*}$ Robert.Lascano@ars.usda.gov
}

Received 12 September 2014; revised 15 October 2014; accepted 2 November 2014

Copyright (C) 2014 by authors and Scientific Research Publishing Inc.

This work is licensed under the Creative Commons Attribution International License (CC BY). http://creativecommons.org/licenses/by/4.0/

(c) (7) Open Access

\section{Abstract}

Information on cotton evapotranspiration (ET) during the seedling growth stage and under field conditions is scarce because $E T$ is a difficult parameter to measure. Our objective was to use weighable lysimeters to measure daily values of cotton seedling $E T$. We designed and built plastic weighable micro-lysimeters (ML) that were $0.35 \mathrm{~m}$ deep with a soil volume of $6300 \mathrm{~cm}^{3}$. The soil core was obtained in-situ by pushing the ML well casing into the soil using a commercial soil sampler. The soil core was weighed with tension and compression type load-cells, where a change

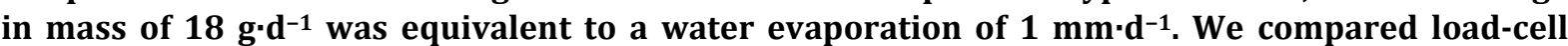
measurements of changes in mass to values measured with a portable field scale by linear regression analysis, and the slope was equal to 1 , indicating no statistical difference $(P=0.05)$ between the two measurements. We measured and compared seedling height, root length and leaf area of cotton plants in the ML with cotton plants in the surrounding area and this comparison showed that the ML used was suitable to measure cotton seedling $E T$ for the first 30 days after seed emergence. The root mean squared error for crop height was $0.09 \mathrm{~cm}$, for leaf area index (LAI) was 0.03 $\mathrm{m}^{2} \cdot \mathrm{m}^{-2}$ and $6.5 \mathrm{~cm}$ for root length. Also, soil temperature at a $0.1 \mathrm{~m}$ depth was statistically $(P=$ 0.05 ) the same in and outside the ML's. For two planting dates, we measured daily values of soil water evaporation $(E)$ and cotton seedling $E T$. The day following an irrigation event, $E$ was $\sim 9 \mathrm{~mm}$

\footnotetext{
${ }^{*}$ Corresponding author.

"The U.S. Department of Agriculture (USDA) prohibits discrimination in all its programs and activities on the basis of race, color, national origin, age, disability, and where applicable, sex, marital status, familial status, parental status, religion, sexual orientation, genetic information, political beliefs, reprisal, or because all or part of an individual's income is derived from any public assistance program.
} 
$\mathrm{d}^{-1}$ and quickly declined the following days. Results showed that ML's provide an accurate tool to measure water losses from the soil and cotton plants with a LAI of $\leq 0.2$.

\title{
Keywords
}

\author{
Cotton Seedling, Lysimeter, Evapotranspiration, Transpiration, Water Use, Field Measurement
}

\section{Introduction}

Upland cotton (Gossypium hirsutum L.) is the major field crop grown on the Texas High Plains even though common early-season biological and environmental constraints can have negative effects on lint yield. For example, these negative factors include soil particle abrasion on cotton seedling plants due to high wind speed, insufficient precipitation, hail, extreme air temperatures, pathogens, and damage from pests. Of all biotic and abiotic stresses, plant available soil water is the most limiting but manageable factor for irrigated cotton production on the Texas High Plains [1] [2]. It is well recognized that the first 40 days after planting is a critical stage to manage a cotton crop to achieve maximum lint yield potential [1]-[4]. Even as irrigation water from the Ogallala aquifer declines, cotton remains a viable crop for the Texas High Plains producers [5]. A great deal of knowledge has been gathered on cotton physiology, water and nutrient requirements, and other environmental factors that affect cotton productivity; however, much of this work has focused on the middle to late vegetative and late reproductive stages of cotton growth stages. Information on cotton evapotranspiration (ET) under field conditions and in the early stages of crop growth is limited.

The developmental stages of cotton are divided into five growth stages: 1) germination and emergence; 2) seedling establishment; 3) leaf area and canopy development; 4) flowering and boll development; and 5) maturation [4] [6]. Also, the cotton plant, given its indeterminate growth habit, i.e., simultaneously producing vegetative and reproductive growth, for a long period of time (130 - 180 days) makes cotton structurally complex compared to other field crops [7]. The wide range of soils and climates where cotton is grown along with its indeterminate growth habit is a challenge to manage the many biotic and abiotic stresses that impact cotton lint yield [5] [8].

The effect of biotic and abiotic stresses on cotton seedling emergence, growth and development is the subject of several studies. For example, soil water content a few days after soil abrasion was key to plant survival, and 3-day-old cotton plants had a higher survival rate with increased soil water compared to 9-day-old plants with the same soil water content [9]. Krieg and Carroll [10] reported that minimal air temperatures limited non-lipid metabolism causing reductions in cotton seedling growth rates. McMichael and Quisenberry [11] discussed several soil environmental factors including temperature, soil water and nutrients, and soil strength that impact cotton root growth and development. Reddy et al. [12] found that cold air temperatures during seed emergence reduced cotton seedling biomass and subsequent growth rates. Pace et al. [13] found that while cotton root dry weight was less in the non-drought stressed plants, tap-root length was greater in the non-stressed plants. Baker [14] studied the abrasion of cotton seedlings and their recovery from windblown sand. The above examples illustrate the impact of biotic and abiotic stresses on cotton seedlings and their subsequent effects on $E T$ and lint yield.

Measuring crop ET under field conditions is challenging even on well-developed crops, and is more complicated during the early stages of plant growth when the leaf canopy is small and the leaf area index (LAI) is $<1$. Under field conditions, a common method to measure crop ET and its two components, soil water evaporation $(E)$ and plant transpiration $(T)$, is gravimetrically by using weighing lysimeters. A discussion on the history and design of lysimeters and their use for measuring water use by vegetation is given by [15] and a review of methods to measure and calculate crop $E T$ is given by [16]. In general, weighable lysimeters are useful to measure crop ET, but often they are large and expensive to install and cannot partition $E$ and $T$. Examples of large weighing lysimeters are given by [15] [17]-[21]. Smaller lysimeters, i.e., mini- and micro-lysimeters, have also been used to measure $E, T$ and $E T$ on smaller scales and examples are given by [22]-[31]. Hereafter, no distinction is made between mini- and micro-lysimeters and they are abbreviated as ML.

The ML's have been coupled with other instrumentation, including dual-probe heat-pulse, stem flow gauges, 
and time domain reflectometery to measure the amount of soil water loss through $E$ and $E T$ [31]-[35]. These ML's are normally installed and weighed early in the morning and then again weighed in evening hours using a portable scale and thus provide an estimate of day time values of soil $E$ and $E T$. In addition, load cells have been used with ML's providing an automated and continuous record of weight, which can then be used to calculate evaporative losses of water due to $E$ and $E T$ [28] [36] [37].

The concept of designing a ML to measure $E, T$ and $E T$ requires isolating a soil volume that can repeatedly be weighed and then use changes in mass to calculate the rate of water loss. It is assumed that inside and outside soil conditions are similar and thus it is of particular importance to minimize the disturbance of the soil surface in the ML [23]. With time the soil water content and temperature profile inside the ML will deviate from that of the surrounding soil and after several days $E$ and $T$ from the ML may no longer be representative of the surrounding field, particularly when plants are present. However, these limitations are minimized by using a ML material with low thermal conductivity such as plastic and by using lengths $\geq 0.3 \mathrm{~m}$ as suggested by [26]. In general and for a bare soil, the wall material of the ML affects the vertical temperature distribution, but not $E$, provided that ML's are replaced every day [25] [27]. When a plant is in the ML, root growth will be constrained by the inside soil volume and after several days the measured $E T$ may be underestimated, compared to the $E T$ of the surrounding field. The larger the soil volume of a ML the longer a single ML can be used to measure ET before it has to be replaced and the measured $E T$ values are not representative. It is evident that ML is a tool that has many advantages measuring cotton ET of plants under field conditions and in the initial stages of crop growth stage, i.e., seedling stage.

Other methods available to measure crop ET under field conditions lack the necessary resolution to measure the daily ET during the early stages of crop growth [16]. For example, by measuring the soil volumetric water content $\left(\theta_{v}\right)$ over the depth of the root zone it is possible to calculate the change in soil water storage and estimate crop ET. These measurements of $\theta_{v}$ require calibrated soil water sensors that respond to electromagnetic properties, such as time domain reflectometery, ground penetrating radar, and capacitance methods [38]-[40]. The well-known neutron attenuation method is not included because of its limitation to correctly measure the $\theta_{v}$ in the surface layer, where fast neutrons escape to the atmosphere making it difficult to accurately measure the soil water content of the surface layer. The hourly and daily crop ET of cotton plants during the seedling stage is on the order of $0.5 \mathrm{~mm} \cdot \mathrm{h}^{-1}$ and $3 \mathrm{~mm} \cdot \mathrm{d}^{-1}$, respectively [41]. For example, a daily $T$ of $3 \mathrm{~mm}$ for a $0.3 \mathrm{~m}$ root-depth represents a change in $\theta_{v}$ of $\pm 0.01 \mathrm{~m}^{3} \cdot \mathrm{m}^{-3}$, which exceeds the accuracy of the majority of the commercial sensors available to measure $\theta_{v}$ [42]. Therefore, the measurement of daily values of crop ET in the early stages of crop growth and under field conditions require a gravimetric method such as lysimetry or by using whole plant chambers such as those described by [43] [44]. In these chambers, differentials of incoming and outgoing $\mathrm{H}_{2} \mathrm{O}$ and $\mathrm{CO}_{2}$ concentrations are used to calculate plant $E T$ and net assimilation using an infrared gas analyzer. These chambers provide an excellent tool to measure whole plant $E T$ from emergence to first-square; however, the necessary equipment is expensive. Conversely, gravimetric measurements simply require a weighing scale and in terms of equipment are less expensive than other methods.

On the Texas High Plains, plant available soil water is the most limiting factor in cotton production and the first 40 - 60 days after planting is a critical stage to manage the cotton crop to achieve maximum lint yield potential. However, information on water use by cotton plants from emergence to first-square, in the seedling growth stage, and under field conditions is rare. Therefore, the objective of this study was to evaluate the measurement of seedling cotton ET using lysimetric techniques under field conditions.

\section{Materials and Methods}

The laboratory and fieldwork were done at the facilities of the United States Department of Agriculture-Agricultural Research Service (USDA-ARS), Cropping Systems Research Laboratory in Lubbock, TX (33.59 $\mathrm{N}$, $101.89^{\circ} \mathrm{W}$, and average elevation of $960 \mathrm{~m}$ above sea level). Laboratory evaluations were done during the fall season of 2009 and field measurements were done during the summer of 2010. In our evaluation of ML's to measure cotton seedling ET we built ML's with and without load cells. Our field evaluations were done with cotton planted on two dates, i.e., 12 May and 22 June 2010. The layout of the experimental field used to evaluate the ML's is shown in Figure 1(a) and the location where ML's were installed is shown in Figure 1(b).

It was of interest to determine the duration whereby the ML's used to measure the seedling ET were representative of cotton plants in the surrounding area and thus we measured and compared the crop height, leaf area 


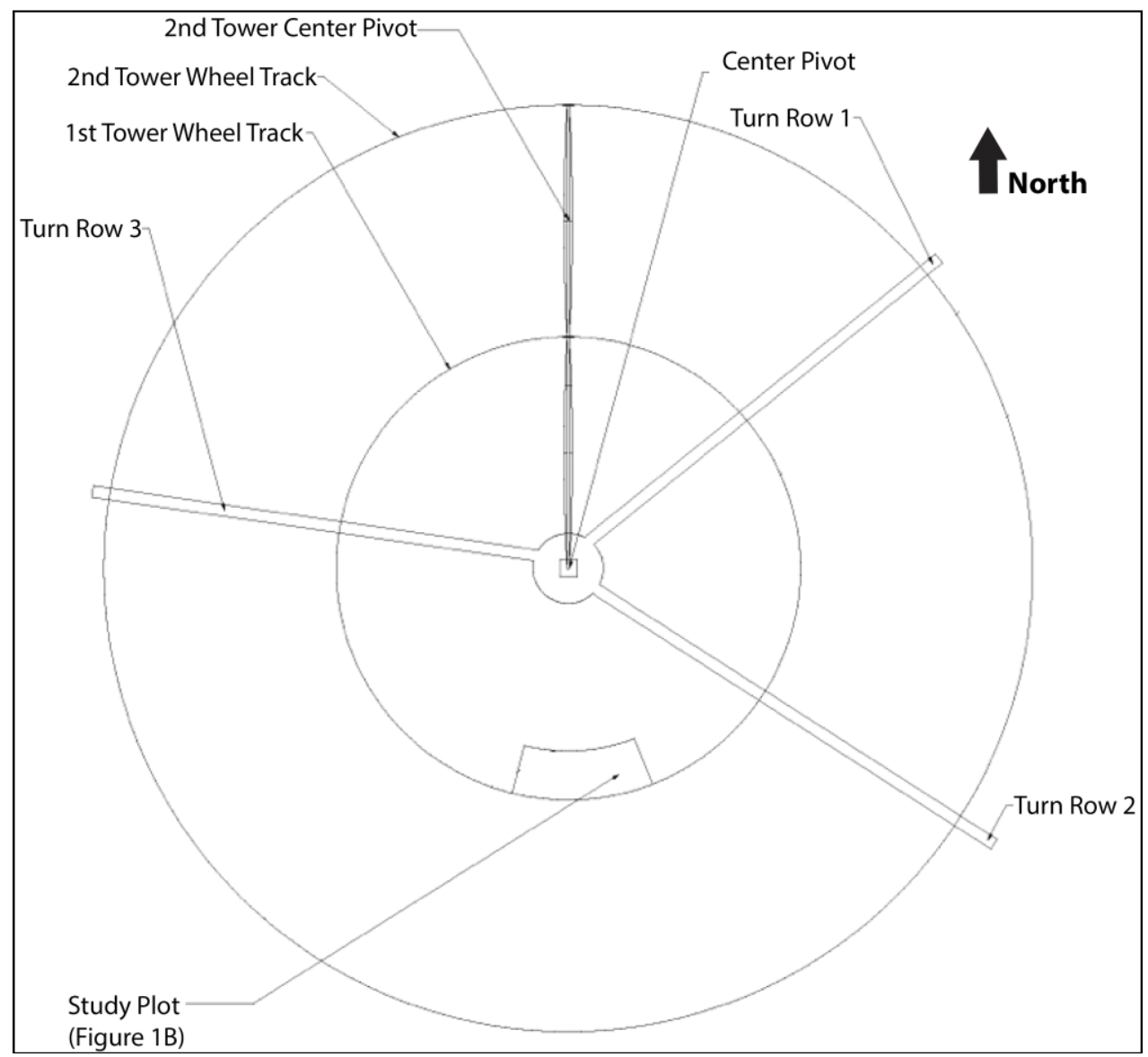

(a)

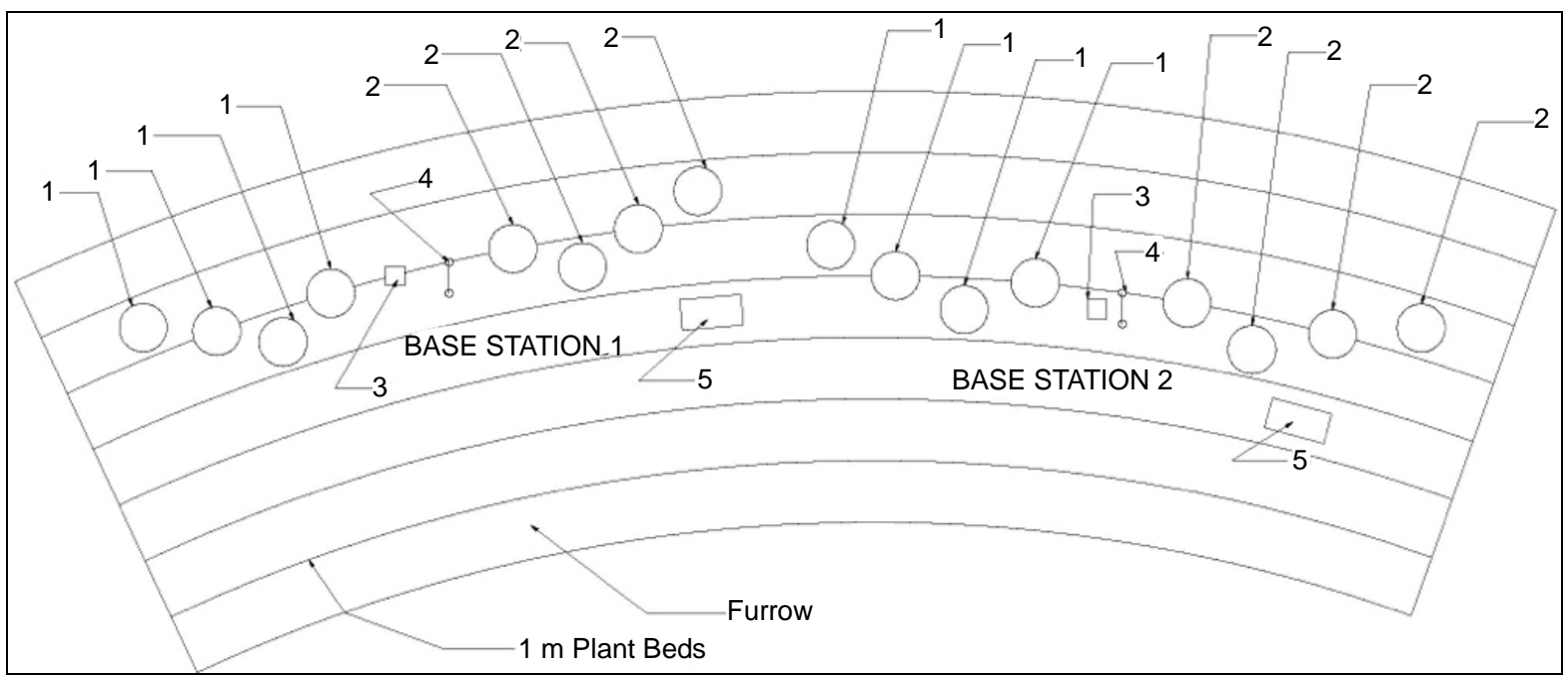

(b)

Figure 1. (a) Layout of the experimental field used to evaluate micro-lysimeters, showing the $110 \mathrm{~m}$ long center pivot with two spans and turn rows used to access the study plot. The center pivot is located on the facilities of the Cropping Systems Research Laboratory, USDA-ARS in Lubbock, TX $\left(33.59^{\circ} \mathrm{N}, 101.89^{\circ} \mathrm{W}\right)$. (b) The experimental plot, 8 rows wide and $25 \mathrm{~m}$ long, showing location of micro-lysimeters $(M L)$ to measure soil water evaporation $(E)$ and cotton seedling evapotranspiration $(E T)$. The numbers 1 and 2 are locations where ML's were installed in the planted row or in between rows, $1 \mathrm{~m}$ apart. The Base Station is the location of portable field scale. Number 3 shows location of rain gauges; number 4 shows location of soil thermocouples, and 5 shows location of datalogger used to weigh ML's with load-cells. The field plot was $\sim 200 \mathrm{~m}^{2}$. 
and root length (RL) of cotton seedlings in the ML's to cotton plants in the surrounding area. These measurements were done on cotton seedlings for both planting dates. Crop height was measured every day after emergence on cotton seedling in the ML's (Figure 1(b)) and on ten cotton seedlings in closed proximity. At the end of each of the planting trials, we measured in the laboratory the leaf area of cotton seedlings in each ML's using a leaf area meter (Model LI-3100C Area Meter, Li-Cor, Lincoln, NE). The leaf area of cotton seedlings on the surrounding area was measured on plants harvested in three 1-m lengths of row. These plants were collected on the same date as those plants from the ML's. The RL was measured using the line-transect method of Newman [45] on the cotton roots of each plant in the ML that were washed with water and separated from the soil. The leaf area and RL was measured in each of the 8 ML's shown in Figure 1(b).

Soil temperature was measured inside and outside ML's using Type-T thermocouples connected to a datalogger (CR3000 Campbell Sci. Inc., Logan, UT) from the 7 to the 21 June and from the 1 to 31 July in 2010. Thermocouples were installed at a depth of $10 \mathrm{~cm}$ from the soil surface inside the ML and directly into the soil in close proximity to the ML. These measurements were replicated at four locations in the field (Figure 1(b)).

\subsection{Site Description}

The soil of the experimental area is classified in the Amarillo soil series (fine-loamy, mixed, Thermic, Aridic Paleustalf) and soil physical and hydraulic properties are given by [46]. This area is characterized by a semi-arid climate, with warm summer air temperatures, high wind speed and erratic rainfall distribution. For Lubbock, TX the long-term monthly average grass reference evapotranspiration $\left(E T_{0}\right)$ ranges from a low of $2 \mathrm{~mm} \cdot \mathrm{d}^{-1}$ in December to a high of $7.5 \mathrm{~mm} \cdot \mathrm{d}^{-1}$ in June. In Lubbock, TX the mean annual rainfall is $474 \pm 144 \mathrm{~mm}$ and the distribution is characterized by a relatively dry winter period with most of the rain during the growing season, May to September [8] [47]. The experimental site was irrigated with a 110-m long center pivot (Zimmatic ${ }^{1}$, Omaha, NE) system with two spans, covering $\sim 4$ ha (Figure 1(a)).

Experimental Plot. The outside span of the center pivot was planted with grain sorghum (Sorghum bicolor) and the inside span was planted with cotton. All planting was in circular bedded rows that were $\sim 1 \mathrm{~m}$ apart. An area, $200 \mathrm{~m}^{2}$ (8 rows of cotton and $\sim 32 \mathrm{~m}$ long) within the inside span, $32 \mathrm{~m}$ from the center of the pivot, was used to evaluate the ML's to measure cotton ET (Figure 1(b)). To evaluate the ML's under field conditions, cotton (FiberMax-9180 ${ }^{\circledR}$, Bayer Crop Science, Research Triangle Park, NC) was planted on two dates on 1-m bedded rows as shown in Figure 1(b). The planting date for the first field trial was 12 May 2010 and 22 June 2010 for the second planting date. Emergence dates were 23 May and 27 June for each planting date, respectively. Stand counts averaged 20 plants $\mathrm{m}^{-1}$ for both planting dates. The purpose of these two planting dates was to have access to cotton plants in the seedling growth stage and evaluate the ML's to measure $E$ from bare soil and cotton seedling ET. Grain sorghum (NK7633, Chromatin, New Deal, TX) was planted, 1 m bedded circular rows, on the 4 May 2010 in the outside span of the center pivot (Figure 1(a)).

\subsection{Micro-Lysimeters (ML)}

The weighable ML's designed and used in our experiments consisted of four basic components and the item number given in the ML description are shown in Figure 2. A lysimeter that holds the soil and/or plant (item 4); a rubber cap at the bottom of the lysimeter (item 5); load-cell (item 2) that weighs the lysimeter and two plates (item 3); and casing that allows the lysimeter to freely move and be weighed with the load-cell (item 6). The lysimeter was constructed from $15.2 \mathrm{~cm}$ inside diameter schedule 40 polyvinylchloride (PVC) pipe cut to $35 \mathrm{~cm}$ lengths (item 4). This size was selected because the plant available water for an Amarillo soil is about 0.25 $\mathrm{m}^{3} \cdot \mathrm{m}^{-3}$ [46] and thus the soil in the ML could store $\sim 90 \mathrm{~mm}$ of water, which could supply cotton seedlings $\sim 3$ $\mathrm{mm} \cdot \mathrm{d}^{-1}$ of water for 30 days. We selected and used PVC pipe because of its low thermal conductivity $(0.19 \mathrm{~W}$ $\mathrm{m}^{-1} \cdot{ }^{\circ} \mathrm{C}^{-1}$ ) and because lengths $\geq 0.3 \mathrm{~m}$ allow measurements up to nine consecutive days without having to change the ML's as suggested by [26].

A critical element in the design of a weighing ML is that the lysimeter (item 4) holding the soil and/or plant should be able to move freely without obstruction from another wall or part of the lysimeter. For this purpose, and to measure the changes in mass as a function of time we built sleeves, i.e., casing walls (item 6) constructed of $20.3 \mathrm{~cm}$ inside diameter schedule 40 PVC pipe cut to 56-cm length. The casing ensured that the soil around

\footnotetext{
${ }^{1}$ Mention of this or other proprietary products is for the convenience of the readers only and does not constitute endorsement or preferential treatment of these products by USDA-ARS.
} 


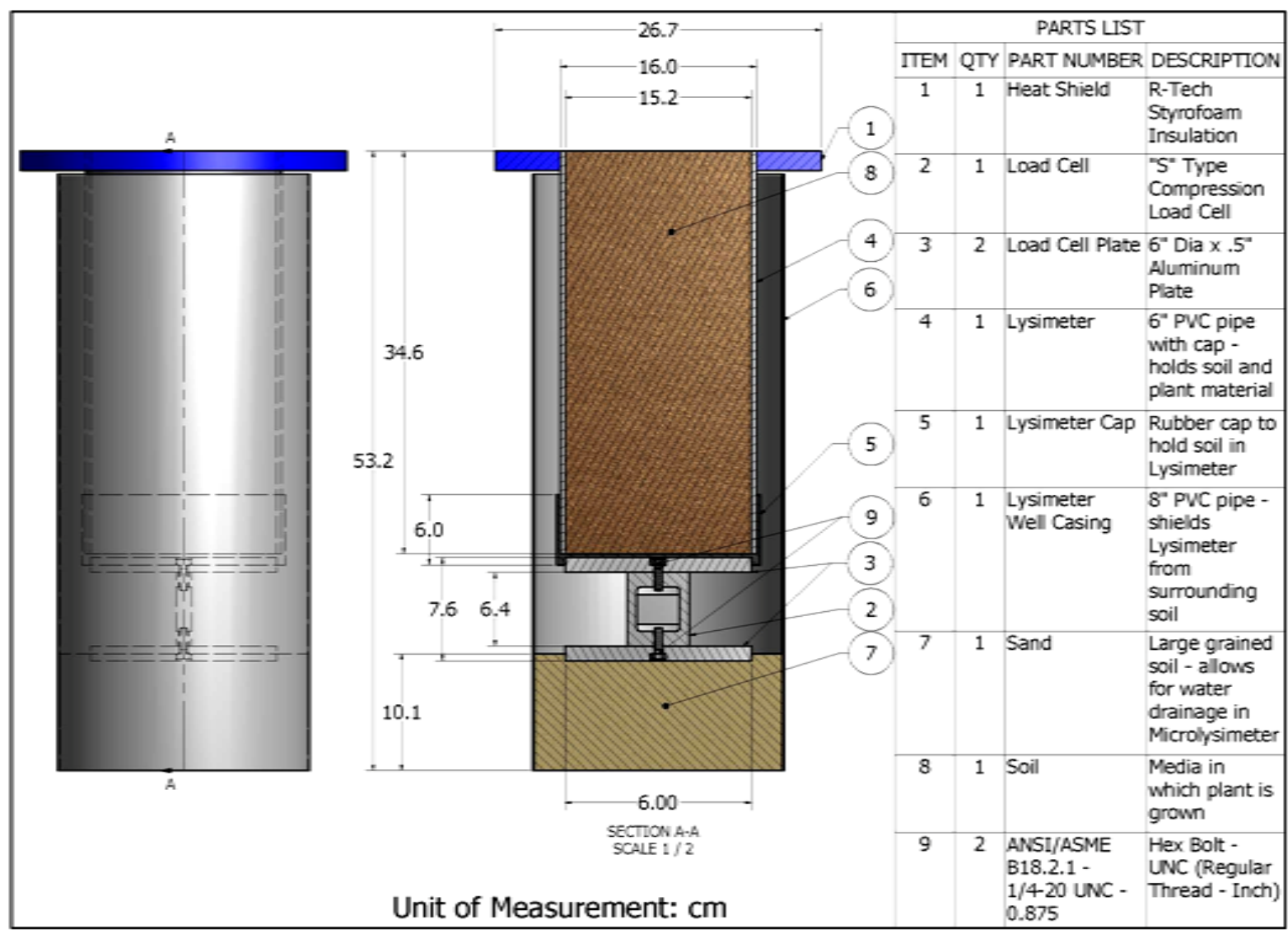

Figure 2. Design of micro-lysimeters used to measure soil water evaporation $(E)$ and cotton seedling evapotranspiration (ET). Also given are parts list with item number $(1$ - 9), quantity of each item, part number and description.

the ML would not collapse and allowed the installation of a load-cell (item 2) to weigh the ML. Coarse sand was used to form a $10 \mathrm{~cm}$ base at the bottom of each casing well to allow water drainage (item 7). When the ML's were positioned in the casing wells, the top of the ML was $\sim 1 \mathrm{~cm}$ above the surface of the soil.

Load-Cells. To measure changes in mass with the ML's we selected s-beam tension and compression type load-cells (LSB302, Futek Advanced Sensor Technology Inc., Irvine, CA) shown as item 2. These load-cells have a maximum weighing capacity of $23 \mathrm{~kg}$. The load-cell assembly was comprised of two circular aluminum plates (12.7 mm Height $\times 152.4$ mm Diameter) (item 3) that were bolted (item 9) to each load-cell (item 2). The load-cell electromotive force (emf, mV) output was sampled with a datalogger (CR3000 Campbell Sci. Inc., Logan, UT) at a frequency of $0.2 \mathrm{~Hz}$ and averages were calculated and stored at $30 \mathrm{~min}$ intervals. The wires, 3 $6 \mathrm{~m}$ in length, of each load-cell were taped to the inside wall casing of the lysimeter emerging at the top and then connected to the datalogger. Care was taken that the load-cell wires did not interfere with the free movement of the lysimeter.

Load-Cell Calibration. Each load-cell used in the ML's was calibrated under laboratory conditions by placing certified calibration weights (Mettler-Toledo, Columbus, $\mathrm{OH}$ ) on the load-cell plate, over a 0.01 to $20.0 \mathrm{~kg}$ range, and registering the corresponding emf output (mV). For the ML's built and selected load-cells a change in mass of $18.15 \mathrm{~g} \cdot \mathrm{d}^{-1}$ was equivalent to an evaporative water loss of $1.0 \mathrm{~mm} \cdot \mathrm{d}^{-1}$.

Load-Cell Evaluation. Daily measurements of $E$ and $E T$ obtained with ML's with load cells were compared to values measured with a portable field scale (Model CBC32, Adam Equipment Co., Danbury, CT, maximum capacity of $32 \mathrm{~kg}$, readability of $1 \mathrm{~g}$ ). For this purpose, sixteen ML's divided into two groups of eight, were selected and installed as shown in Figure 1(b). In this arrangement, 8 ML's were on either side of the bed, giving a measure of $E$ and the other eight ML's were on the planted row, giving a measure of cotton seedling ET. All 16 of these ML's were manually weighed daily at $0700 \mathrm{~h}$ CST for a period of 15 days during the first planting period and 18 days during the second planting period. 
Field ML Installation. An undisturbed in-situ soil core was obtained by setting the lysimeter (item 4) on the soil surface and placing an aluminum plate $(0.2 \times 0.3 \mathrm{~m})$ on top that was used to push item 4 into the soil using a soil-sampling machine (Giddings Machine Company Inc., Windsor, CO). In this step care was taken to minimize compacting the soil inside the lysimeter and disturbing the soil surface. The lysimeter was pushed until the top was flush with the soil surface and thereafter excavated with shovels and the 'soil core' was carefully cut at the bottom and rubber cap (item 5) was then placed on the bottom. The 'soil core' with the rubber cap on the bottom was moved over and placed in a casing (either on top of a load cell or on an additional $10 \mathrm{~cm}$ of sand in place of a load cell). The dug hole was made deep and large enough to accommodate item 6 , such that the top was $\sim 1 \mathrm{~cm}$ above the soil surface. With item 6 in place, the bottom was filled with a $10 \mathrm{~cm}$ layer of coarse sand (item 7), and the bottom load-cell plate (item 3) along with the load-cell (item 2) and top load-cell plate were assembled using two bolts (item 9). The final step in the field installation was to place a circular piece (item 1) of $20 \mathrm{~mm}$ thick Styrofoam insulation (R-Tech ${ }^{\circledR}$, Insulfoam, Tacoma, WA) around the outer edge of the lysimeter as shown in Figure 2. With the heat shield in place, item 4 was placed on top of the load-cell plate.

The installation of ML's without load-cells was similar as previously described, except that only the in-situ soil core (item 4) was interred. Again, item 4 was inserted by placing the aluminum plate on top of the well casing and pushing into the soil using the Giddings soil-sampling machine. Once the top of item 4 was flush with the soil surface a rubber cap (item 5) was placed on the bottom of the excavated soil core. Again, care was taken to minimize disturbance of the soil surface and compacting the soil inside the lysimeter.

\section{Results and Discussion}

Our objective was to evaluate weighing ML's to measure the daily ET of cotton seedlings under field conditions. This objective was prompted by the lack of information on the water use of cotton in the early stages of growth, which is critical to manage and achieve maximum lint yield potential. We selected a gravimetric method that when used to measure ET requires isolating a soil volume with plants growing in it that can be weighed repeatedly. The plants growing in the lysimeter must be similar to surrounding plants so that the in-situ measurements of crop ET are representative of field conditions.

\subsection{Leaf Area Index (LAI) and Root Length (RL)}

Using plant height (data not shown) as a criterion to determine when cotton seedlings in the ML were different than plants in the field we determined that the ML's used provided a period of about 30 days after emergence (Table 1). The root mean square error (RMSE) for the crop height was $0.9 \mathrm{~cm}$. The first planting date (12 May) and the second planting date (22 June) provided 15 and 18 days, respectively of comparisons of load-cell and manually weighed measurements of cotton seedling ET. However, we also compared the measured LAI and RL of cotton seedlings in and outside the ML, and these results are given in Table 1. For both planting dates, the average measured LAI of cotton seedlings inside and outside the ML was similar. During the first planting date

Table 1. Average measured leaf area index (LAI, $\mathrm{m}^{2} \cdot \mathrm{m}^{-2}$ ) and root length (RL, $\mathrm{cm}$ ) in the micro-lysimeter (ML) and field and corresponding standard error (SE) for the first and second planting dates. Also, given is the day of year (DOY) and days after seed emergence. The ML measurements were done on the eight cotton plants shown in Figure 1(b).

\begin{tabular}{|c|c|c|c|c|c|c|}
\hline Date, 2010 & DOY & $\begin{array}{l}\text { Days after } \\
\text { Emergence }\end{array}$ & $\begin{array}{c}\text { Average ML } \\
\mathrm{LAI} \pm \mathrm{SD}\left[\mathrm{m}^{2} \cdot \mathrm{m}^{-2}\right]\end{array}$ & $\begin{array}{c}\text { Average Field } \\
\text { LAI } \pm \text { SE }\end{array}$ & $\begin{array}{l}\text { Average ML } \\
\text { RL } \pm \text { SE [cm] }\end{array}$ & $\begin{array}{c}\text { Average Field } \\
\text { RL } \pm \text { SE }\end{array}$ \\
\hline \multicolumn{7}{|c|}{ First Planting Date-12 May } \\
\hline 9 June & 161 & 17 & $0.08 \pm 0.011$ & $0.07 \pm 0.020$ & $35.1 \pm 2.5$ & $41.2 \pm 2.2$ \\
\hline 14 June & 166 & 22 & $0.14 \pm 0.018$ & $0.12 \pm 0.022$ & $43.9 \pm 2.2$ & $46.6 \pm 3.2$ \\
\hline 22 June & 174 & 30 & $0.24 \pm 0.024$ & $0.28 \pm 0.030$ & $45.3 \pm 2.5$ & $52.2 \pm 3.2$ \\
\hline \multicolumn{7}{|c|}{ Second Planting Date-22 June } \\
\hline 7 July & 189 & 6 & $0.04 \pm 0.001$ & $0.03 \pm 0.001$ & $19.9 \pm 2.3$ & $21.5 \pm 2.1$ \\
\hline 14 July & 196 & 13 & $0.07 \pm 0.005$ & $0.09 \pm 0.024$ & $37.1 \pm 2.3$ & $39.9 \pm 2.9$ \\
\hline 22 July & 204 & 21 & $0.11 \pm 0.007$ & $0.12 \pm 0.022$ & $52.1 \pm 2.9$ & $55.2 \pm 2.1$ \\
\hline 29 July & 211 & 28 & $0.13 \pm 0.007$ & $0.18 \pm 0.017$ & $51.7 \pm 1.3$ & $65.2 \pm 3.5$ \\
\hline
\end{tabular}


the average LAI of cotton seedlings in the ML, increased from $0.08 \mathrm{~m}^{2} \cdot \mathrm{m}^{-2}$ to $0.25 \mathrm{~m}^{2} \cdot \mathrm{m}^{-2}$ over a period of 13 days and the corresponding LAI, outside the ML's, increased from $0.07 \mathrm{~m}^{2} \cdot \mathrm{m}^{-2}$ to $0.28 \mathrm{~m}^{2} \cdot \mathrm{m}^{-2}$. For the second planting date, the average LAI of plants in the ML's increased from $0.04 \mathrm{~m}^{2} \cdot \mathrm{m}^{-2}$ to $0.13 \mathrm{~m}^{2} \cdot \mathrm{m}^{-2}$ over a period of 22 days and for the field grown plants the average LAI increased from $0.03 \mathrm{~m}^{2} \cdot \mathrm{m}^{-2}$ to $0.18 \mathrm{~m}^{2} \cdot \mathrm{m}^{-2}$. The RMSE for LAI was $0.03 \mathrm{~m}^{2} \cdot \mathrm{m}^{-2}$.

For both planting dates, the measured RL of cotton seedlings in the ML were slightly lower than for plants grown in the surrounding area (Table 1). For example, for the first planting date the average RL for cotton seedlings in the ML's increased from $35.1 \mathrm{~cm}$ to $45.3 \mathrm{~cm}$ over a period of 13 days and the corresponding RL for outside plants increased from $41.2 \mathrm{~cm}$ to $52.2 \mathrm{~cm}$. A similar result was obtained for the second planting date. However, for both planting dates, the coefficient of variation (standard deviation/average) of measured RL was on average $18 \%$, indicating that statistically there was no difference of RL for cotton seedlings in and outside the ML. The RMSE for the RL was $6.5 \mathrm{~cm}$.

\subsection{Soil Temperature}

An example of hourly measured soil temperature on a single ML for a 2-day period, 12 - 13 June (DOY 164 and 165), and in the surrounding soil is shown in Figure 3. During early morning hours the ML soil temperature is $\sim 0.5^{\circ} \mathrm{C}$ cooler than the surrounding soil and as the day progresses the ML soil temperature increases and is $\sim 1^{\circ} \mathrm{C}$ warmer at 1800 hours. The two soil temperatures tend to equilibrate, as expected, during nighttime, and the pattern from the previous day repeats (Figure 3). The average hourly soil temperature in and outside the $4 \mathrm{ML}$ 's for a 12-day period from 11 to 21 June (DOY 161 to 173) is shown in Figure 4 and the linear regression comparing the inside and outside soil temperature is shown in Figure 5 . The hourly pattern of measured soil temperature in and outside a single ML (Figure 3) is repeated for the 12 days shown in Figure 4. The soil temperature in the ML is cooler that the outside soil in the morning hours before sunrise and as the day progresses the ML soil temperature is warmer than the outside soil (Figure 4). The linear regression shows a correlation coefficient $\left(\mathrm{r}^{2}\right)$ of 0.91 and a slope of 0.76 over a range from $25^{\circ} \mathrm{C}$ to $33^{\circ} \mathrm{C}$ (Figure 5). These results show that the in-situ field installation of ML's had a minimal impact on the soil temperature inside and outside at a depth of $0.1 \mathrm{~m}$ across the temperature ranges reported in this study. This comparison was done for a continuous 12 day (Figure 4) and 33 day (DOY 176 - 209) period (data not shown). For example, on DOY 209, after 33 days of the ML remaining in-situ, the hourly pattern shown on DOY 164 - 165 (Figure 3) was the same. From these measurements we can conclude that the effect of isolating a soil volume with a ML on soil temperature at a $0.1 \mathrm{~m}$ depth for a 30-day period is minimal.

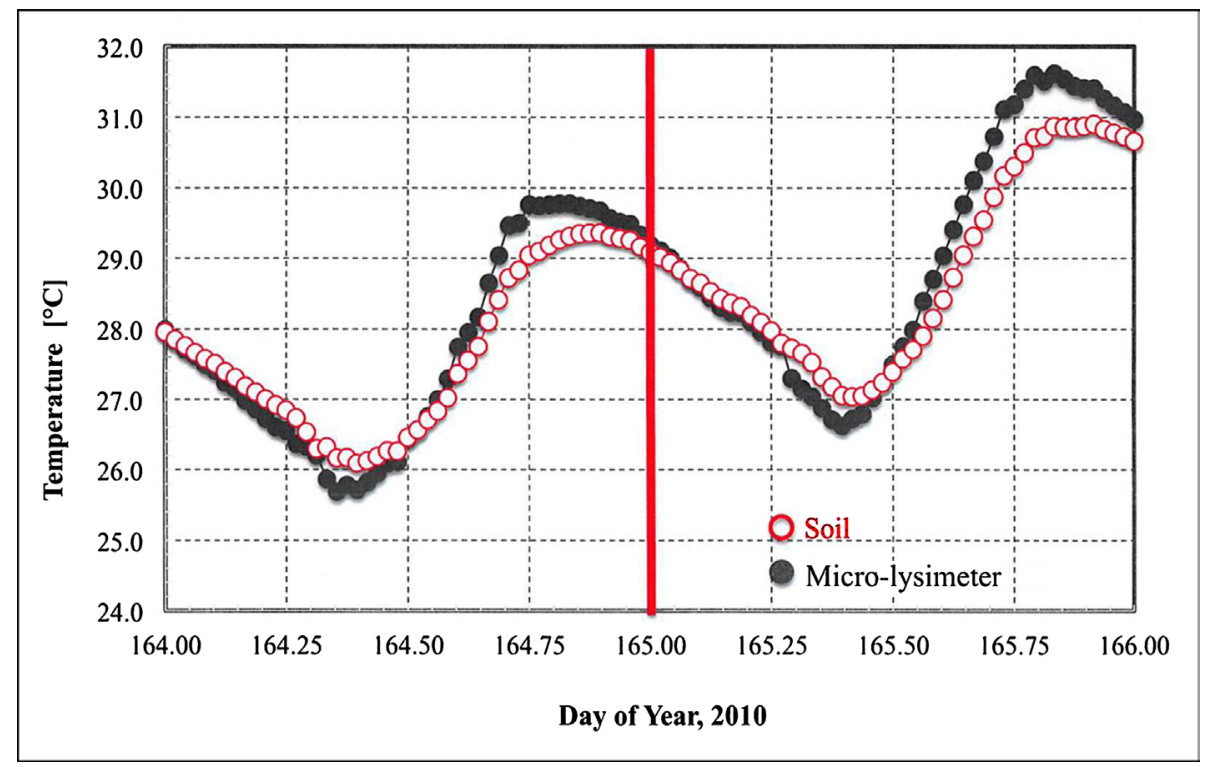

Figure 3. Measured soil temperature, $10 \mathrm{~cm}$ depth, inside the micro-lysimeter (ML) and in the soil in close proximity to the ML. 


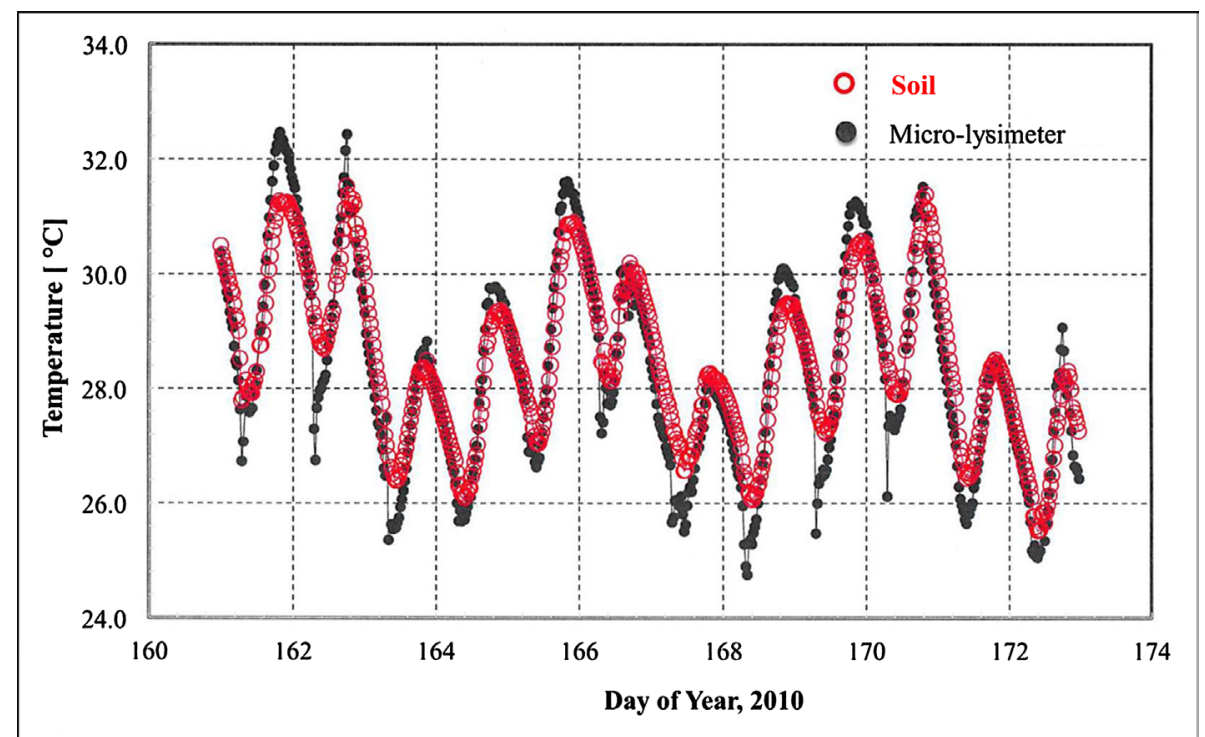

Figure 4. Measured average soil temperature inside and outside four micro-lysimeters for a period of 12 days from DOY 161 to DOY 173 in the experimental plot shown in Figure 1(b).

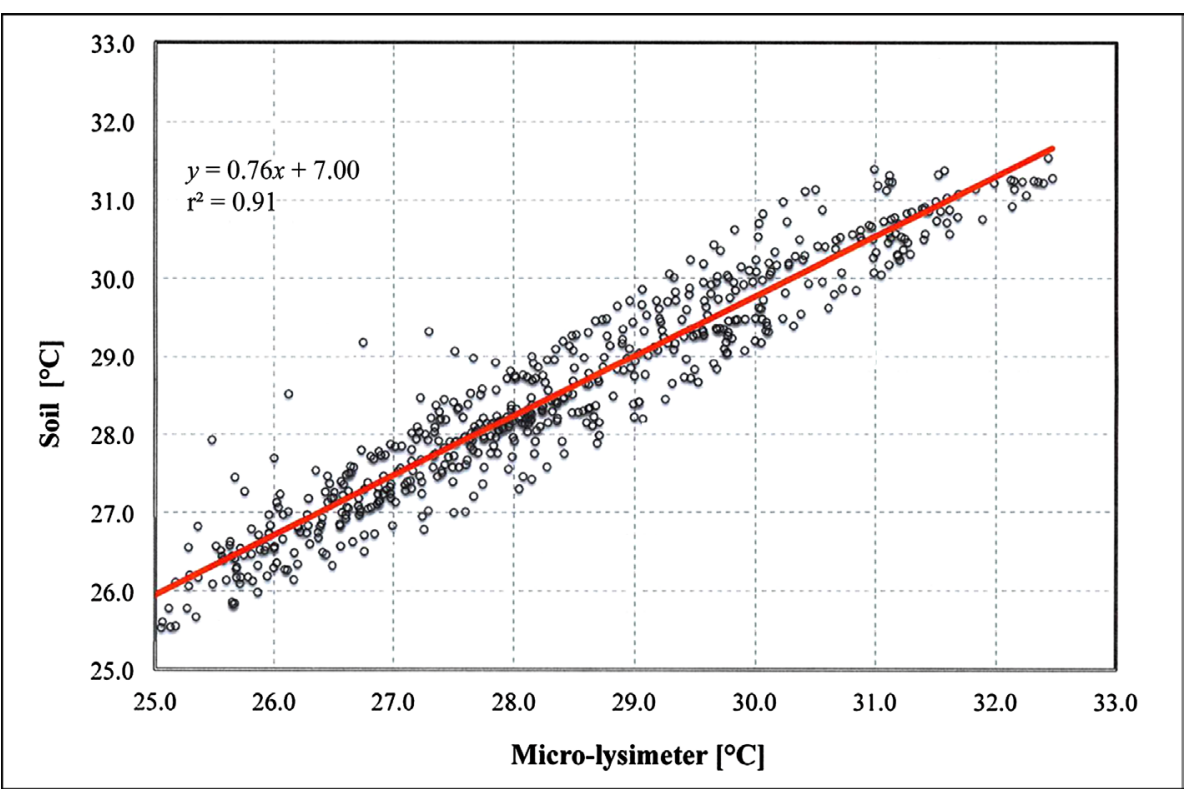

Figure 5. Linear regression and coefficient of correlation $\left(r^{2}\right)$ of measured soil temperature inside and outside micro-lysimeters for the 12-day period from DOY 161 to DOY 173.

\subsection{Soil Water Evaporation $(E)$ and Cotton Seedling Evapotranspiration $(E T)$}

The measurement of hourly and daily soil water $E$ and plant $E T$ with in-situ ML's under field conditions is a gravimetric method that is accurate and involves the repeated measurement of the mass of an isolated soil volume as a function of time [16]. To obtain hourly values of cotton seedling ET the ML's were weighed with load-cells (Figure 2) and daily values of ET were compared to values obtained with a portable field scale. The comparison of daily values of $E$ and $E T$ obtained with the portable field scale and load-cells are shown in Figure 6. The linear regression for the cotton seedling $E T$ was $y=1.01 x$, where $y$ is the scale $E T$ in $\mathrm{mm}^{-1} \mathrm{~d}^{-1}$ and $x$ is the corresponding load-cell $E T$ value in $\mathrm{mm} \cdot \mathrm{d}^{-1}$. For $E$, the linear regression was $y=0.99 x$, where $y$ is the scale- $E$ in $\mathrm{mm} \cdot \mathrm{d}^{-1}$ and $x$ is the corresponding load-cell value of $E \mathrm{in} \mathrm{mm} \cdot \mathrm{d}^{-1}$. We tested if the slopes $(P=0.05)$ where different than 1, i.e., $\mathrm{d} y / \mathrm{d} x \neq 1$, showing that there were no differences between values of $E$ or $E T$ measured with 
the load-cells or portable field scale. Both liner regressions were forced through the origin and yielded an $\mathrm{r}^{2}=$ 0.87 for the $E T$ measurement and an $\mathrm{r}^{2}=0.99$ for the $E$ measurements. These results confirm that a gravimetric method to measure $E$ or $E T$ is accurate [16].

Examples of the 1/2-hourly record of the mass of a single ML on bare soil, a measure of $E$, and of a ML with a cotton seedling, a measure of $E T$, are shown, respectively in Figure 7 and Figure 8. The measurement of 1/2 hourly values of $E$ was for a 12-day period from DOY 161 to 173 (Figure 7). At 0850 hours on DOY 161 the initial mass was $12.5 \mathrm{~kg}$ and remained relatively constant until 1800 hours, increasing to $12.9 \mathrm{~kg}$. This increase in ML mass was a result of a 25-mm irrigation applied by the overhead sprinkler (Figure 1(a)). Thereafter, the mass of the ML gradually decreases as a result of water evaporation from the bare soil. The increase in mass on DOY 170.73 (1700 hours) from $12.3 \mathrm{~kg}$ to $12.6 \mathrm{~kg}$ was again due to a 20 -mm irrigation. The example for the $1 / 2$ hourly values of ML mass with a cotton seedling, also show the increase in ML mass due irrigation applied by the center pivot at the end of DOY 161 and on DOY 170.73 (Figure 8).

The average daily values of $E$ and $E T$ measured with the weighable ML's on both planting dates are shown in Figure 9. The gaps in the data were due to rainfall that precluded access to the plot to weigh ML's with the

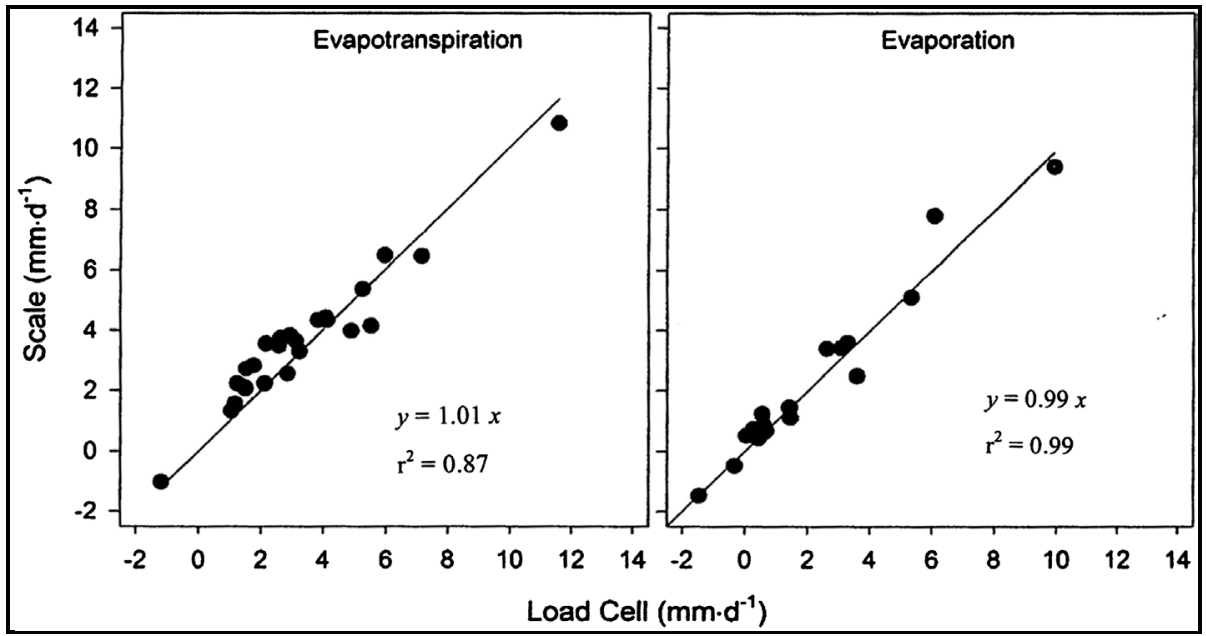

Figure 6. Linear regression and coefficient of correlation $\left(r^{2}\right)$ for daily values of evapotranspiration $\left(\mathrm{mm} \cdot \mathrm{d}^{-1}\right)$ and soil water evaporation $\left(\mathrm{mm} \cdot \mathrm{d}^{-1}\right)$ measured with the portable field scale and micro-lysimeter load-cell.

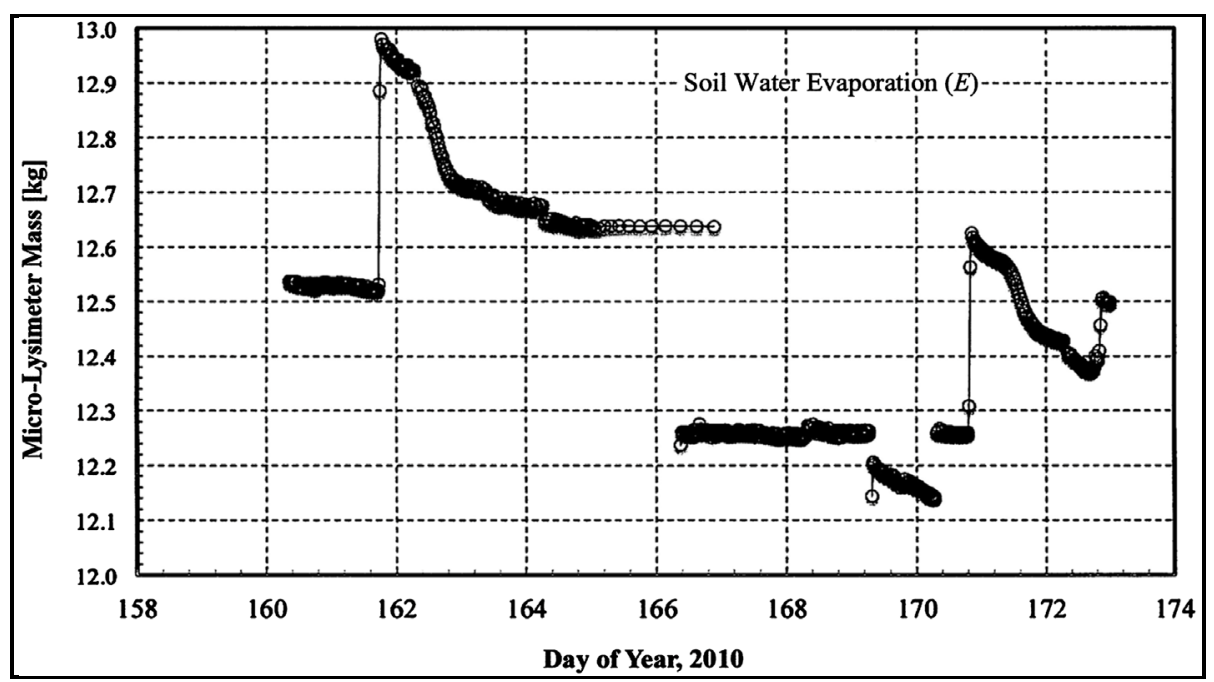

Figure 7. Half-hourly micro-lysimeter mass $(\mathrm{kg})$ measured with a load-cell on a bare soil for 12 days from DOY 161 to DOY 173 and used to calculate soil water evaporation $(E)$ from bare soil. 


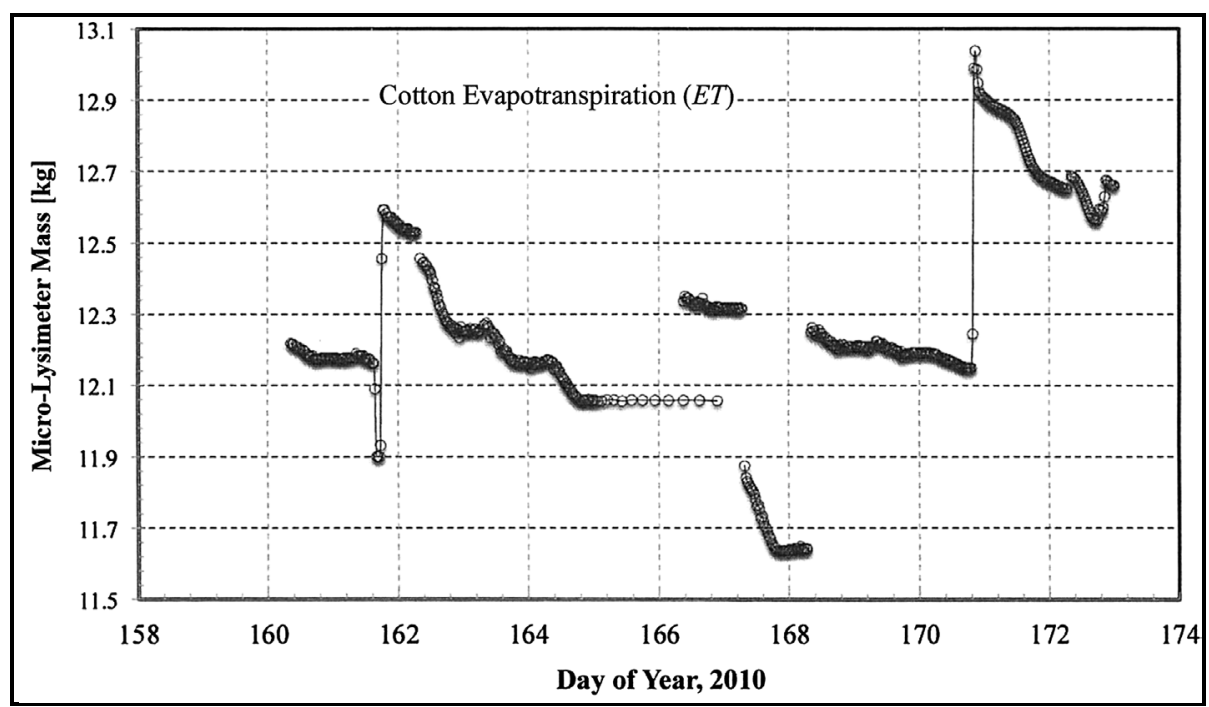

Figure 8. Half-hourly micro-lysimeter mass $(\mathrm{kg})$ measured with a load-cell on a cotton seedling for 12 days from DOY 161 to DOY 173 and used to calculate cotton seedling evapotranspiration $(E T)$.

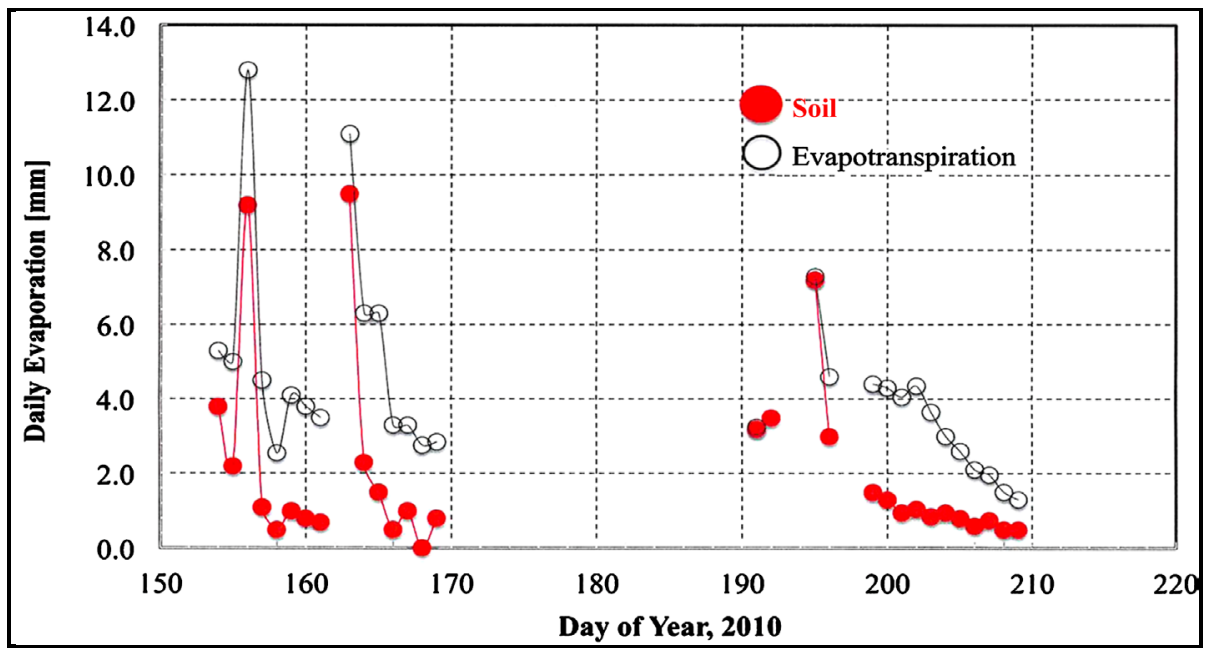

Figure 9. Average daily values of measured soil water evaporation $(E)$ and cotton seedling (ET) for both planting dates. The first planting study started on DOY 154 and ended on DOY 169. The second planting study started on DOY 191 and ended on DOY 209.

portable field scale. The values of $E$ ranged from a low of $\sim 0.5 \mathrm{~mm} \cdot \mathrm{d}^{-1}$ on several days (DOY 158, 166 - 167 , and DOY 208 - 209) to a high of $9.2 \mathrm{~mm} \cdot \mathrm{d}^{-1}$ on DOY 156 and $9.5 \mathrm{~mm} \cdot \mathrm{d}^{-1}$ on DOY 163 for the first planting date and a high of $7.2 \mathrm{~mm} \cdot \mathrm{d}^{-1}$ on DOY 195 for the second planting date. These high values of $E$ can be expected on the Amarillo soil series, particularly after an irrigation or rainfall event where a high rate of $E$ is followed by a much lower value immediately afterwards, i.e., $9.5 \mathrm{~mm} \cdot \mathrm{d}^{-1}$ on DOY 163 to $2.3 \mathrm{~mm} \cdot \mathrm{d}^{-1}$ on DOY 164, and 1.5 $\mathrm{mm}$ on DOY 165 [48] [49]. The daily values of $E T$ ranged from a low of $\sim 0.5 \mathrm{~mm} \cdot \mathrm{d}^{-1}$, measured on several days on both planting dates, to high values of $12.8 \mathrm{~mm} \cdot \mathrm{d}^{-1}$ on DOY 156 and $11.1 \mathrm{~mm} \cdot \mathrm{d}^{-1}$ on DOY 163 . However, the majority of $E T$ was due to a high value of $E$. The ability to separate $E$ from $E T$ provides an estimate of plant transpiration $(T)$ values, which are low early in the growing season and increase as plants grow and develop [41] [49].

Information on evaporative losses of water from the soil and the plant, throughout the growing season, is an important subject in cropping systems research for both dryland and irrigated crops [41] [50]. In managing water from either rain or irrigation, a frequent goal is to minimize the evaporative losses of water from the soil and to 
increase crop transpiration. This requires information on two of three components of $E T$, e.g., $E$ and $T, E$ and $E T$, or $T$ and $E T$, where the third and unknown component is calculated as the residual one. The field measurement of $E, T$ and $E T$ is difficult, particularly early in the growing season when plants are in the seedling growth stage [16]. This has led to the development of simulation models to calculate the partitioning of $E T$ into its two components $E$ and $T$ [8] [16] [41] [49] [51]. The daily calculated ratio of $E / E T$ for the two planting dates is given in Figure 10. As expected in the seedling stage the majority of the evaporative losses are due to $E$. For example, immediately after irrigation the E/ET ratio was $~ 70 \%$ on DOY $154 \%$ and $86 \%$ on DOY 153 during the first planting date. The $E / E T$ was $98 \%$ on DOY 195 after the field was irrigated and the crop's LAI was $0.07 \mathrm{~m}^{2} \cdot \mathrm{m}^{-2}$ (Table 1) during the second planting date. The measured cumulative daily ET was $78 \mathrm{~mm}$ and $52 \mathrm{~mm}$, respectively for the first and second planting dates. For the first planting date the cumulative E/ET was $45 \%$ and $52 \%$ for the second planting date. As expected this ratio will decrease as the plants grow and a larger proportion of the $E T$ is due to $T$. The seasonal E/ET of an irrigated cotton crop in the Texas High Plains was 30\% [41] and for a dryland cotton crop the $E / E T$ was $50 \%$ and reduced to $31 \%$ when the dryland crop was planted in a wheat residue [49] [50].

Examples of the 1/2-hourly record of the mass of a single ML on bare soil, a measure of $E$, and of a ML with a cotton seedling, a measure of $E T$, are shown, respectively in Figure 7 and Figure 8. The measurement of 1/2 hourly values of $E$ was for a 12-day period from DOY 161 to 173 (Figure 7). Starting on DOY 161 the initial mass was $12.5 \mathrm{~kg}$ at 0850 hours and remained relatively constant until 1800 hours, increasing to $12.9 \mathrm{~kg}$. This increase in ML mass was a result of a 25-mm irrigation applied by the overhead sprinkler (Figure 1(a)). Thereafter, the mass of the ML gradually decreases as a result of water evaporation from the bare soil. The increase in mass on DOY 170.73 (1700 hours) from $12.3 \mathrm{~kg}$ to $12.6 \mathrm{~kg}$ was again due to a $20-\mathrm{mm}$ irrigation. The example for the $1 / 2$ hourly values of ML mass with a cotton seedling, also show the increase in ML mass due irrigation applied by the center pivot at the end of DOY 161 and on DOY 170.73 (Figure 8).

The average daily values of $E$ and $E T$ measured with the weighable ML's on both planting dates are shown in Figure 9. The gaps in the data were due to rainfall that precluded access to the plot to weigh ML's with the portable field scale. The values of $E$ ranged from a low of $\sim 0.5 \mathrm{~mm} \cdot \mathrm{d}^{-1}$ on several days (DOY 158, 166 - 167, and DOY 208 - 209) to a high of $9.2 \mathrm{~mm} \cdot \mathrm{d}^{-1}$ on DOY 156 and $9.5 \mathrm{~mm} \cdot \mathrm{d}^{-1}$ on DOY 163 for the first planting date and a high of $7.2 \mathrm{~mm} \cdot \mathrm{d}^{-1}$ on DOY 195 for the second planting date. These high values of $E$ can be expected on the Amarillo soil series, particularly after an irrigation or rainfall event where a high rate of $E$ is followed by a much lower value immediately afterwards, i.e., $9.5 \mathrm{~mm} \cdot \mathrm{d}^{-1}$ on DOY 163 to $2.3 \mathrm{~mm} \cdot \mathrm{d}^{-1}$ on DOY 164, and 1.5 $\mathrm{mm}$ on DOY 165 [48] [49]. The daily values of $E T$ ranged from a low of $\sim 0.5 \mathrm{~mm} \cdot \mathrm{d}^{-1}$, measured on several days on both planting dates, to high values of $12.8 \mathrm{~mm} \cdot \mathrm{d}^{-1}$ on DOY 156 and $11.1 \mathrm{~mm} \cdot \mathrm{d}^{-1}$ on DOY 163 . However, the majority of $E T$ was due to a high value of $E$. The ability to separate $E$ from $E T$ provides an estimate of

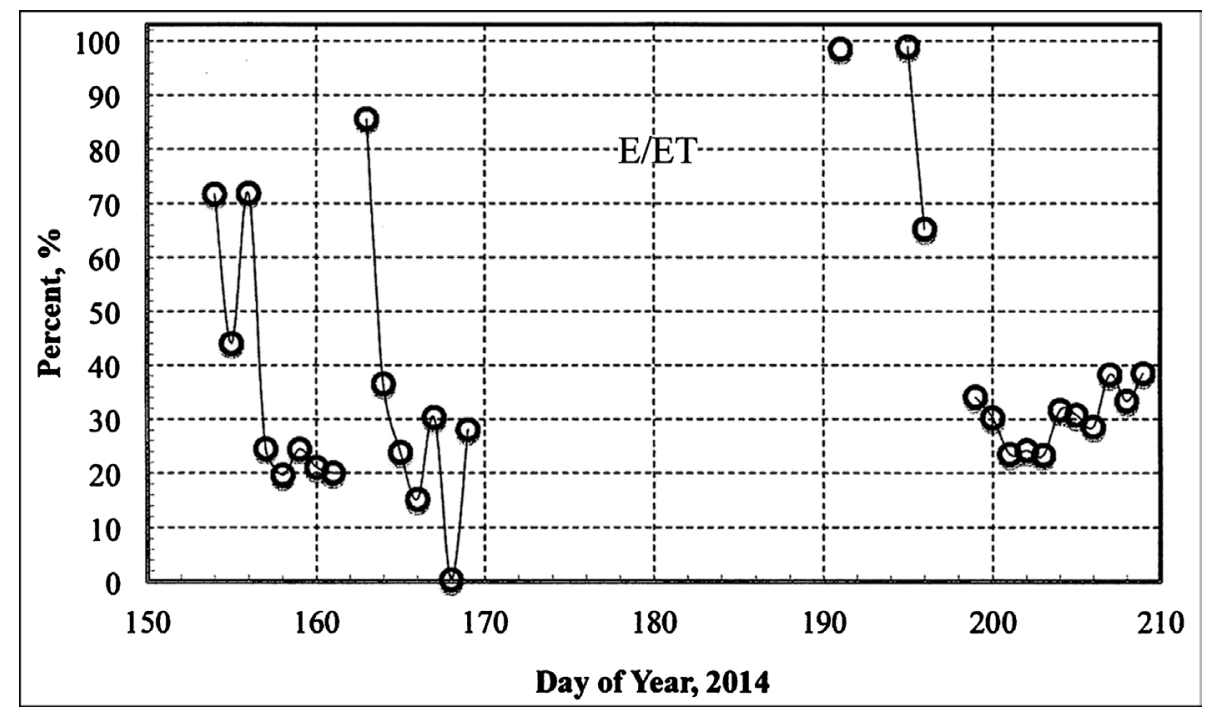

Figure 10. The ratio of daily soil water evaporation $(E)$ to cotton seedling evapotranspiration $(E T)$ in percent for the duration of the two planting studies. 
plant transpiration $(T)$ values, which are low early in the growing season and increase as plants grow and develop [41] [49].

Information on evaporative losses of water from the soil and the plant, throughout the growing season, is an important subject in cropping systems research for both dryland and irrigated crops [41] [50]. In managing water from either rain or irrigation, a frequent goal is to minimize the evaporative losses of water from the soil and to increase crop transpiration. This requires information on two of three components of $E T$, e.g., $E$ and $T, E$ and $E T$, or $T$ and $E T$, where the third and unknown component is calculated as the residual one. The field measurement of $E, T$ and $E T$ is difficult, particularly early in the growing season when plants are in the seedling growth stage [16]. This has led to the development of simulation models to calculate the partitioning of ET into its two components $E$ and $T$ [8] [16] [41] [49] [51]. The daily calculated ratio of $E / E T$ for the two planting dates is given in Figure 10. As expected in the seedling stage the majority of the evaporative losses are due to $E$. For example, immediately after irrigation the E/ET ratio was $~ 70 \%$ on DOY 154 and $86 \%$ on DOY 153 during the first planting date. The $E / E T$ was $98 \%$ on DOY 195 after the field was irrigated and the crop's LAI was $0.07 \mathrm{~m}^{2} \cdot \mathrm{m}^{-2}$ (Table 1) during the second planting date. The measured cumulative daily $E T$ was $78 \mathrm{~mm}$ and $52 \mathrm{~mm}$, respectively for the first and second planting dates. For the first planting date the cumulative E/ET was $45 \%$ and $52 \%$ for the second planting date. As expected this ratio will decrease as the plants grow and a larger proportion of the $E T$ is due to $T$. The seasonal E/ET of an irrigated cotton crop in the Texas High Plains was 30\% [41] and for a dryland cotton crop the $E / E T$ was $50 \%$ and reduced to $31 \%$ when the dryland crop was planted in a wheat residue [49] [50].

\section{Summary and Conclusions}

Our objective was to design and build weighing ML's to measure the ET of cotton seedlings under field conditions. We built ML's made of plastic material that were $35 \mathrm{~cm}$ deep, surface area of $181 \mathrm{~cm}^{2}$ and a volume of $6300 \mathrm{~cm}^{3}$ that were installed in-situ using a soil-sampling machine that was used to push the plastic tube into the soil to obtain an undisturbed soil core. The soil core was weighed with load-cells that provided a continuous record of the changes in mass due to evaporation of water from the soil and the cotton plant. A change in mass of $18 \mathrm{~g} \cdot \mathrm{d}^{-1}$ was equivalent to a water evaporation of $1 \mathrm{~mm} \cdot \mathrm{d}^{-1}$. We compared load-cell measurements of changes in mass to values measured with a portable field scale by linear regression analysis, and the slope was equal to 1 , indicating no statistical difference $(P=0.05)$ between the two measurements.

To establish the duration whereby the micro-lysimeters used to measure the seedling $E T$ were representative of cotton plants in the surrounding area, we measured and compared the crop height, leaf area and RL of cotton seedlings in the ML's to cotton plants in the surrounding area. Also, we measured and compared the soil temperature at $10 \mathrm{~cm}$ inside ML's with cotton seedlings and the surrounding soil for several days. The measurements of crop height, leaf area and RL suggested that the ML's used were suitable to measure cotton seedling $E T$ for the first 30 days after seed emergence. Also, the measured soil temperature at a $10 \mathrm{~cm}$ depth was statistically $(P=0.05)$ the same in and outside the micro-lysimeters. For two planting dates, we measured daily values of $E$ and cotton seedling $E T$. As expected in the seedling stage, the majority of the evaporative losses are due to $E$. For example, after an irrigation event, the $E / E T$ ratio was $\sim 70 \%$ and $86 \%$ the following day. The measured cumulative daily $E T$ was $78 \mathrm{~mm}$ for the first planting date and $52 \mathrm{~mm}$ for the second planting date. For the first planting date the cumulative E/ET was $45 \%$ and $52 \%$ for the second planting date. This ratio decreases as the plants grow and a larger proportion of the $E T$ is due to $T$. Results showed that ML's provide an accurate tool to measure water losses from the soil and cotton plants with a LAI of $\leq 0.2$.

\section{Acknowledgements}

This research was supported in part by the Ogallala Aquifer Program, a consortium between USDA-Agricultural Research Service, Kansas State University, Texas A \& M AgriLife Research, Texas A \& M AgriLife Extension Service, Texas Tech University, and West Texas A \& M University. We also thank Cotton Incorporated for their support.

\section{References}

[1] Krieg, D.R. (2005) Yield Component Analysis of Cotton-Genetic \& Environmental Causes of Variation. Proceedings 
of 2005 Beltwide Cotton Conferences, New Orleans, 4-7 January 2005, 2022-2032.

[2] Krieg, D.R. (2005) Fiber Quality Variation within a Cotton Plant as Affected by Genetics and Environment. Proceedings of 2005 Beltwide Cotton Conferences, New Orleans, 4-7 January 2005, 2380-2385.

[3] Guthrie, D., Banks, J.C. and Edmisten, K. (1995) Capitalizing on Earliness. Cotton Physiology Today, Newsletter of the Cotton Physiology Education Program, National Cotton Council, Volume 6, Number 6, 4 p. http://www.cotton.org/tech/physiology/cpt/Growth/upload/Capitalizing-on-Earliness.pdf

[4] Robertson, B., Bednarz, C. and Burmester, C. (2007) Growth and Development-First 60 Days. Cotton Physiology Today, Newsletter of the Cotton Physiology Education Program, National Cotton Council, Volume 13, Number 2, 5 p. http://www.cotton.org/tech/physiology/cpt/plantphysiology/upload/Growth-and-Development-First-60-Days.pdf).

[5] Gowda, P.H., Baumhardt, R.L., Esparza, A.M., Marek, T.H. and Howell, T.A. (2007) Suitability of Cotton as an Alternative Crop in the Ogallala Aquifer Region. Agronomy Journal, 99, 1397-1403. http://dx.doi.org/10.2134/agronj2006.0275

[6] Oosterhuis, D.M. (1990) Growth and Development of the Cotton Plant. In: Miley, W.N. and Oosterhuis, D.M., Eds., Nitrogen Nutrition in Cotton: Practical Issues, Proceedings of Southern Branch Workshop for Practicing Agronomists, Publications of the American Society of Agronomy, Madison, 1-24.

[7] Grimes, D.W. and El-Zik, K.M. (1990) Cotton. In: Stewart, B.A. and Nielsen, D.R., Eds., Irrigation of Agricultural Crops, Agronomy, American Society of Agronomy, Crop Science Society of America, and Soil Science Society of America, Madison, 741-773.

[8] Lascano, R.J. (2000) A General System to Measure and Calculate Daily Crop Water Use. Agronomy Journal, 92, 821832. http://dx.doi.org/10.2134/agronj2000.925821x

[9] Fryrear, D.W. (1971) Survival and Growth of Cotton Plants Damaged by Windblown Sand. Agronomy Journal, 63, 638-642. http://dx.doi.org/10.2134/agronj1971.00021962006300040038x

[10] Krieg, D.R. and Carroll, J.D. (1978) Cotton Seedling Metabolism as Influenced by Germination Temperature, Cultivar, and Seed Physical Properties. Agronomy Journal, 70, 21-25. http://dx.doi.org/10.2134/agronj1978.00021962007000010006x

[11] McMichael, B.L. and Quisenberry, J.E. (1993) The Impact of the Soil Environment on the Growth of Root Systems. Environmental and Experimental Botany, 33, 53-61. http://dx.doi.org/10.1016/0098-8472(93)90055-K

[12] Reddy, K.R., Reddy, V.R. and Hodges, H.F. (1992) Temperature Effects on Early Season Cotton Growth and Development. Agronomy Journal, 84, 229-237. http://dx.doi.org/10.2134/agronj1992.00021962008400020021x

[13] Pace, P.F., Cralle, H.T., El-Halawany, S.H.M., Cothren, J.T. and Senseman, S.A. (1999) Drought-Induced Changes in Shoot and Root Growth of Young Cotton Plants. Journal of Cotton Science, 3, 183-187.

[14] Baker, J.T. (2007) Cotton Seedling Abrasion and Recovery from Wind Blown Sand. Agronomy Journal, 99, $556-561$. http://dx.doi.org/10.2134/agronj2006.0256

[15] Howell, T.A., Schneider, A.D. and Jensen, M.E. (1991) History of Lysimeter Design and Use for Evapotranspiration Measurements. Proceedings of the International Symposium on Lysimetry, Honolulu, 23-25 July 1991, 1-9.

[16] Baker, J.T., Gitz III, D.C. and Lascano, R.J. (2014) Field Evaluation of Open System Chambers for Measuring Whole Canopy Gas Exchanges. Agronomy Journal, 106, 537-544. http://dx.doi.org/10.2134/agronj2013.0449

[17] Lascano, R.J. (2007) The Soil-Plant-Atmosphere System and Monitoring Technology. In: Lascano, R.J. and Sojka, R.E., Eds., Irrigation of Agricultural Crops, American Society of Agronomy, Crop Science Society of America, and Soil Science Society of America, Madison, 85-115.

[18] Schneider, A.D., Howell, T.A. and Steiner, J.L. (1992) An Evaporation Research Facility Using Monolithic Lysimeters from Three Soils. Applied Engineering in Agriculture, 9, 227-232. http://dx.doi.org/10.13031/2013.25982

[19] Schneider, A.D., Howell, T.A., Moustafa, A.T.A., Evett, S.R. and Abou-Zeid, W. (1998) A Simplified Weighing Lysimeter for Monolithic or Reconstructed Soils. Applied Engineering in Agriculture, 14, 267-273. http://dx.doi.org/10.13031/2013.19388

[20] Marek, T., Piccinni, G., Schneider, A., Howell, T., Jett, M. and Dusek, D. (2006) Weighing Lysimeters for the Determination of Crop Water Requirements and Crop Coefficients. Applied Engineering in Agriculture, 22, 851-856. http://dx.doi.org/10.13031/2013.22256

[21] Evett, S.R., Mazahrih, N.T., Jitan, M.A., Sawalha, M.H., Colaizzi, P.D. and Ayars, J.E. (2009) A Weighable Lysimeter for Crop Water Use Determination in the Jordan Valley, Jordan. Transactions of the ASABE, 52, 155-169. http://dx.doi.org/10.13031/2013.25956

[22] Rogowski, A.S. and Jacoby Jr., E.L. (1977) Assessment of Water Loss Patterns with Microlysimeters. Agronomy Journal, 69, 419-424. http://dx.doi.org/10.2134/agronj1977.00021962006900030022x 
[23] Boast, C.W. and Robertson, T.M. (1982) A “Micro-Lysimeter” Method for Determining Evaporation from Bare Soil: Description and Laboratory Evaluation. Soil Science Society of America Journal, 46, 689-696. http://dx.doi.org/10.2136/sssaj1982.03615995004600040005x.

[24] Boesten, J.J.T.L. and Stroosnijder, L. (1986) Simple Model for Daily Evaporation from Fallow Tilled Soil under Spring Conditions in a Temperate Climate. Netherlands Journal of Agricultural Science, 34, 75-90.

[25] Lascano, R.J. and Hatfield, J.L. (1992) Spatial Variability of Evaporation along Two Transects of a Bare Soil. Soil Science Society of America Journal, 56, 341-346. http://dx.doi.org/10.2136/sssaj1992.03615995005600020002x

[26] Evett, S.R., Warrick, A.W. and Matthias, A.D. (1995) Wall Material and Capping Effects on Microlysimeter Temperatures and Evaporation. Soil Science Society America Journal, 59, 329-336. http://dx.doi.org/10.2136/sssaj1995.03615995005900020009x.

[27] Todd, R.W., Evett, S.R., Howell, T.A. and Klocke, N.L. (2000) Soil Temperature and Water Evaporation of Small Steel and Plastic Lysimeters Replaced Daily. Soil Science, 165, 890-895. http://dx.doi.org/10.1097/00010694-200011000-00007

[28] Martin, E.C., de Oliveira, A.S., Folta, A.D., Pegelow, E.J. and Slack, D.C. (2001) Development and Testing of a Small Weighable Lysimeter System to Assess Water Use by Shallow-Rooted Crops. Transactions of the ASAE, 44, 71-78. http://dx.doi.org/10.13031/2013.2309

[29] Earl, H.J. (2003) A Precise Gravimetric Method for Simulating Drought Stress in Pot Experiments. Crop Science, 43, 1868-1873. http://dx.doi.org/10.2135/cropsci2003.1868

[30] Evett, S.R. and Parkin, G.W. (2005) Advances in Soil Water Content Sensing: The Continuing Maturation of Technology and Theory. Vadose Zone Journal, 4, 986-991. http://dx.doi.org/10.2136/vzj2005.0099

[31] Lage, M.A., Bamouh, A., Karrou, M. and El Mourid, M. (2003) Estimation of Rice Evapotranspiration Using a Microlysimeter Technique and Comparison with FAO Penman-Monteith and Pan Evaporation Methods under Moroccan Conditions. Agronomie, 23, 625-631. http://dx.doi.org/10.1051/agro:2003040

[32] Ham, J.M., Heilman, J.L. and Lascano, R.J. (1990) Determination of Soil Water Evaporation and Transpiration from Energy Balance and Stem Flow Measurements. Agricultural and Forest Meteorology, 52, 287-301. http://dx.doi.org/10.1016/0168-1923(90)90087-M

[33] Baker, J.M. and Spaans, E.J.A. (1994) Measuring Water Exchange between Soil and Atmosphere with TDR-Microlysimetry. Soil Science, 158, 22-30. http://dx.doi.org/10.1097/00010694-199407000-00003

[34] Plauborg, F. (1995) Evaporation from Bare Soil in a Temperate Humid Climate-Measurement Using Microlysimeters and Time Domain Reflectometery. Agricultural and Forest Meteorology, 76, 1-17. http://dx.doi.org/10.1016/0168-1923(94)02215-6

[35] Zhang, Z., Wang, X., Li, X. and Zhang, J. (2005) Soil Evaporation in Artificially Re-Vegetated Desert Area. Journal of Desert Research, 25, 243-248.

[36] Dugas, W.A. and Bland, W.L. (1989) The Accuracy of Evaporation Measurements from Small Lysimeters. Agricultural and Forest Meteorology, 46, 119-129. http://dx.doi.org/10.1016/0168-1923(89)90116-0

[37] Heusinkveld, B.G., Berkowicz, S.M., Jacobs, A.F.G., Holtslag, A.A.M. and Hillen, W.C.A.M. (2006) An Automated Microlysimeter to Study Dew Formation and Evaporation in Arid and Semiarid Regions. Journal of Hydrometeorology, 7, 825-832. http://dx.doi.org/10.1175/JHM523.1

[38] Baumhardt, R.L., Lascano, R.J. and Evett, S.R. (2000) Soil Material, Temperature, and Salinity Effects on Calibration of Multisensor Capacitance Probes. Soil Science Society of America Journal, 64, 1940-1946. http://dx.doi.org/10.2136/sssaj2000.6461940x

[39] McMichael, B. and Lascano, R.J. (2003) Laboratory Evaluation of a Commercial Dielectric Soil Water Sensor. Vadose Zone Journal, 2, 650-654. http://dx.doi.org/10.2136/vzj2003.6500

[40] Evett, S.R. and Parkin, G.W. (2005) Advances in Soil Water Content Sensing: The Continuing Maturation of Technology and Theory. Vadose Zone Journal, 4, 986-991. http://dx.doi.org/10.2136/vzj2005.0099

[41] Lascano, R.J., Van Bavel, C.H.M., Hatfield, J.L. and Upchurch, D.R. (1987) Energy and Water Balance of a Sparse Crop: Simulated and Measured Soil and Crop Evaporation. Soil Science Society of America Journal, 51, 1113-1121. http://dx.doi.org/10.2136/sssaj1987.03615995005100050004x

[42] Evett, S.R., Tolk, J.A. and Howell, T.A. (2006) Soil Profile Water Content Determination: Sensor Accuracy, Axial Response, Calibration, Temperature Dependence, and Precision. Vadose Zone Journal, 5, 894-907. http://dx.doi.org/10.2136/vzj2005.0149

[43] Baker, J.T., Van Pelt, S., Gitz, D.C., Payton, P., Lascano, R.J. and McMichael, B. (2009) Canopy Gas Exchange Measurements of Cotton in an Open System. Agronomy Journal, 101, 52-59. http://dx.doi.org/10.2134/agronj2008.0007x

[44] Baker, J.T., Gitz III, D.C. and Lascano, R.J. (2014) Field Evaluation of Open System Chambers for Measuring Whole 
Canopy Gas Exchanges. Agronomy Journal, 106, 537-544. http://dx.doi.org/10.2134/agronj2013.0449

[45] Newman, E.I. (1966) A Method of Estimating the Total Length of Root in a Sample. Journal of Applied Ecology, 3 , 139-145. http://dx.doi.org/10.2307/2401670

[46] Holman, D., Sridharan, M., Gowda, P., Porter, D., Marek, T., Howell, T. and Moorhead, J. (2014) Gaussian Process Models for Reference ET Estimation from Alternative Meteorological Data Sources. Journal of Hydrology, 517, 28-35. http://dx.doi.org/10.1016/j.jhydrol.2014.05.001

[47] Baumhardt, R.L., Lascano, R.J. and Krieg, D.R. (1995) Physical and Hydraulic Properties of a Pullman and Amarillo Soil on the Texas South Plains. Technical Report No. 95-1, TAES/TAMU/College Station, College Station, 17 p.

[48] Lascano, R.J. and Van Bavel, C.H.M. (1986) Simulation and Measurement of Evaporation from a Bare Soil. Soil Science Society of America Journal, 50, 1127-1132. http://dx.doi.org/10.2136/sssaj1986.03615995005000050007x

[49] Lascano, R.J., Baumhardt, R.L., Hicks, S.K. and Heilman, J.L. (1994) Soil and Plant Water Evaporation from StripTilled Cotton: Measurement and Simulation. Agronomy Journal, 86, 987-994. http://dx.doi.org/10.2134/agronj1994.00021962008600060011x

[50] Lascano, R.J. and Baumhardt, R.L. (1996) Effects of Crop Residue on Soil and Plant Water Evaporation in a Dryland Cotton System. Theoretical and Applied Climatology, 54, 69-84. http://dx.doi.org/10.1007/BF00863560

[51] Kool, D., Agam N., Lazarovitch, N., Heitman, J.T., Sauer, T.J. and Ben-Gal, A. (2014) A Review of Approaches for Evapotranspiration Partitioning. Agricultural and Forest Meteorology, 184, 56-70. http://dx.doi.org/10.1016/j.agrformet.2013.09.003 
Scientific Research Publishing (SCIRP) is one of the largest Open Access journal publishers. It is currently publishing more than 200 open access, online, peer-reviewed journals covering a wide range of academic disciplines. SCIRP serves the worldwide academic communities and contributes to the progress and application of science with its publication.

Other selected journals from SCIRP are listed as below. Submit your manuscript to us via either submit@scirp.org or Online Submission Portal.
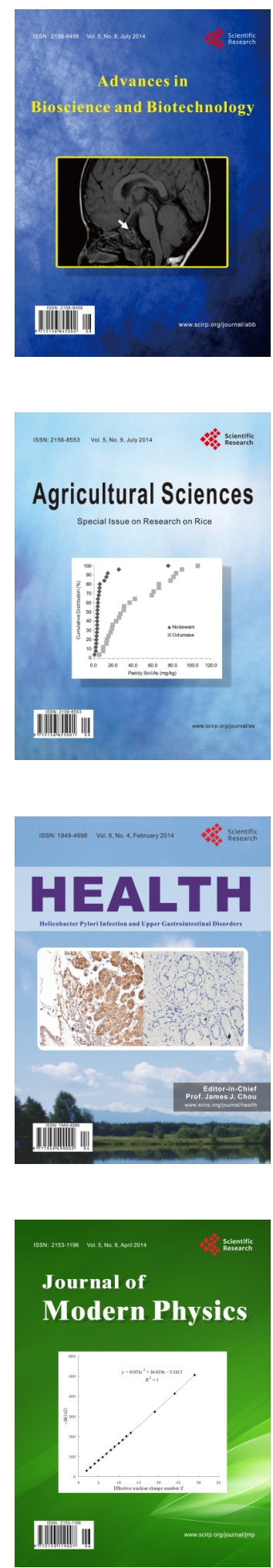
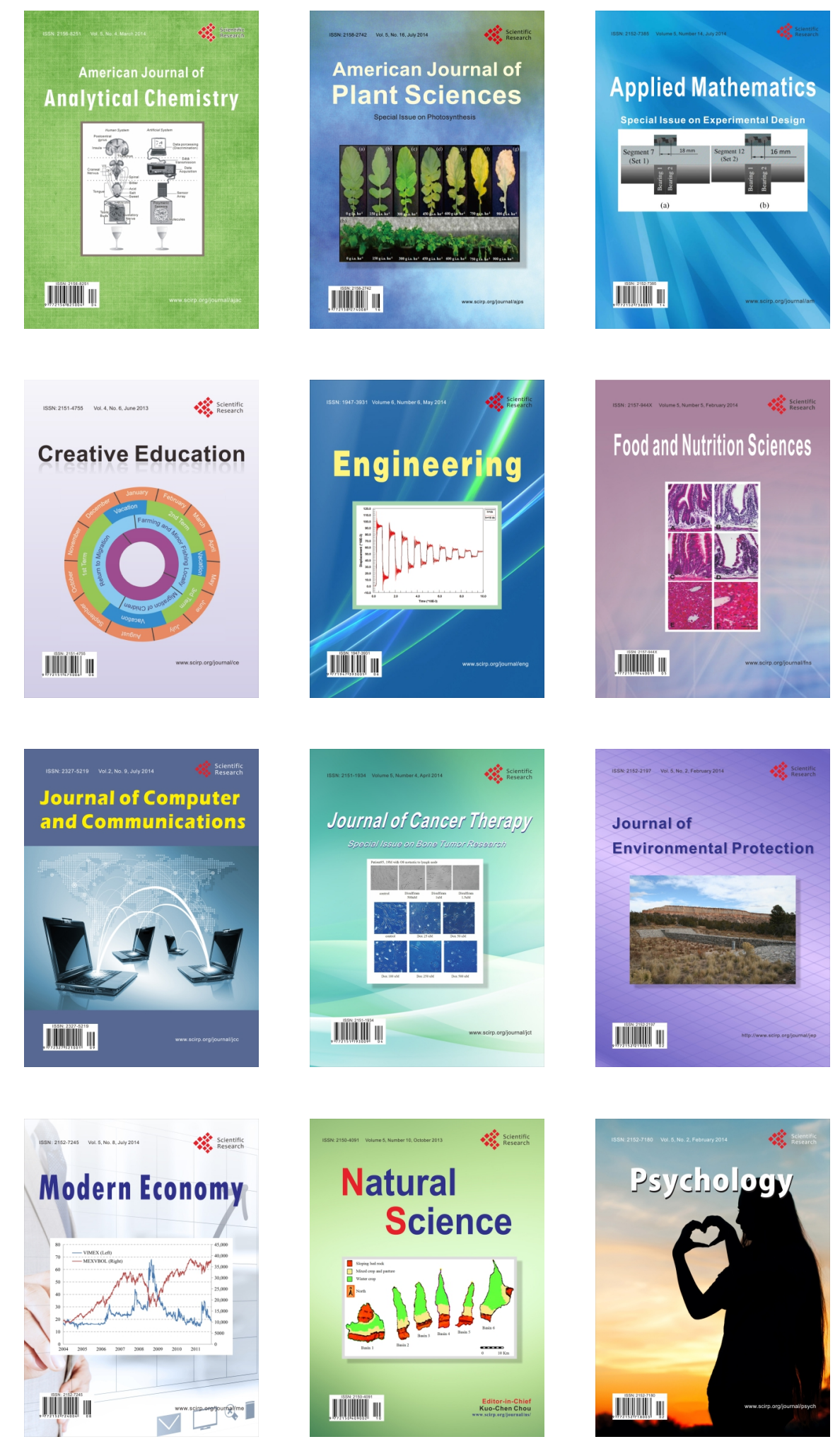